\title{
Methenamine Hippurate
}

National Cancer Institute

\section{Source}

National Cancer Institute. Methenamine Hippurate. NCI Thesaurus. Code C47610.

The hippurate salt form of methenamine, a prodrug and inactive weak base that slowly hydrolyzes in acidic urine to ammonia and the effective, urinary tract antiseptic formaldehyde. Formaldehyde probably exerts its antibacterial effect by denaturation of protein. Depending on the urinary concentrations, formaldehyde is either bactericidal or bacteriostatic. Formaldehyde urinary concentrations are dependent on urine $\mathrm{pH}$, volume, and flow rate. Formaldehyde acts as an antibacterial agent against gram-positive and gram-negative organisms. 